\title{
ОПИСАНИЕ СОРТОВ КАПУСТЫ ДЕКОРАТИВНОЙ СЕЛЕКЦИИ ВНИИССОК
}

Эстафета - среднеспелый сорт декоративной капусты пригодный для потребления в свежем виде, украшения блюд, интерьера, декоративного садоводства. Растение высотой 30-36см в диаметре 30-45 см образует сильнооблиственную розетку с длинночерешковыми поникающими листьями. Лист цельный, округлый с сильногофрированными краями зеленой и светлозеленой окраски. Урожайность - 8-10 кг/м². Содержание витамина С колеблется от 38,72 до 42,24 мг\%, сахаров 0,68 $0,71 \%$, сухого вещества 8,21 - 8,80 \%. Сорт устойчив к пониженным температурам, относительно устойчив к бактериозам, фузариозу, киле.
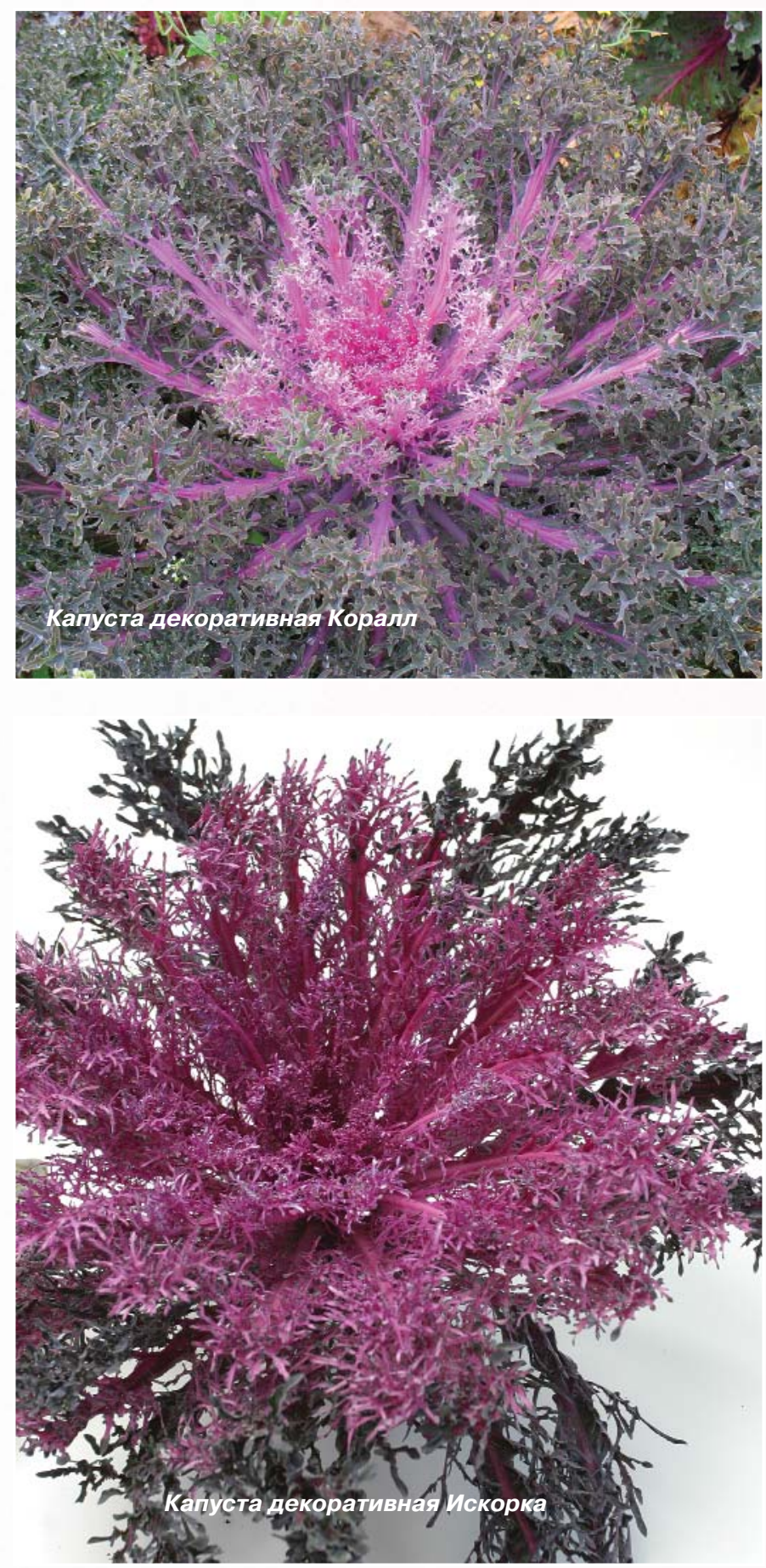

Осенний вальс - среднепоздний сорт декоративной капусты пригодный для выращивания в открытом грунте, потребления в свежем виде, украшения блюд, интерьера, декоративного садоводства. Растения образует компактно-приподнятую розетку диаметром 45 см высотой от 55 до 75 см со среднечерешковым листом, количество которых колеблется от 60 до 85 штук. Лист округлый с фиолетово-зелёной окраской, сильно-волнистым краем и слабым восковым налётом. Поверхность листа гладкая с сильной нервацией. Длина черешка составляет 12 см. Урожайность 15-17 кг/м². Содержание витамина С колеблется от 40,48 до 45,7мг\%, сахаров 0,68-0,7\%, содержание сухого вещества от 8,38 до 8,98\%.Сорт устойчив к бактериозам, листогрызущим вредителям и пониженным температурам.
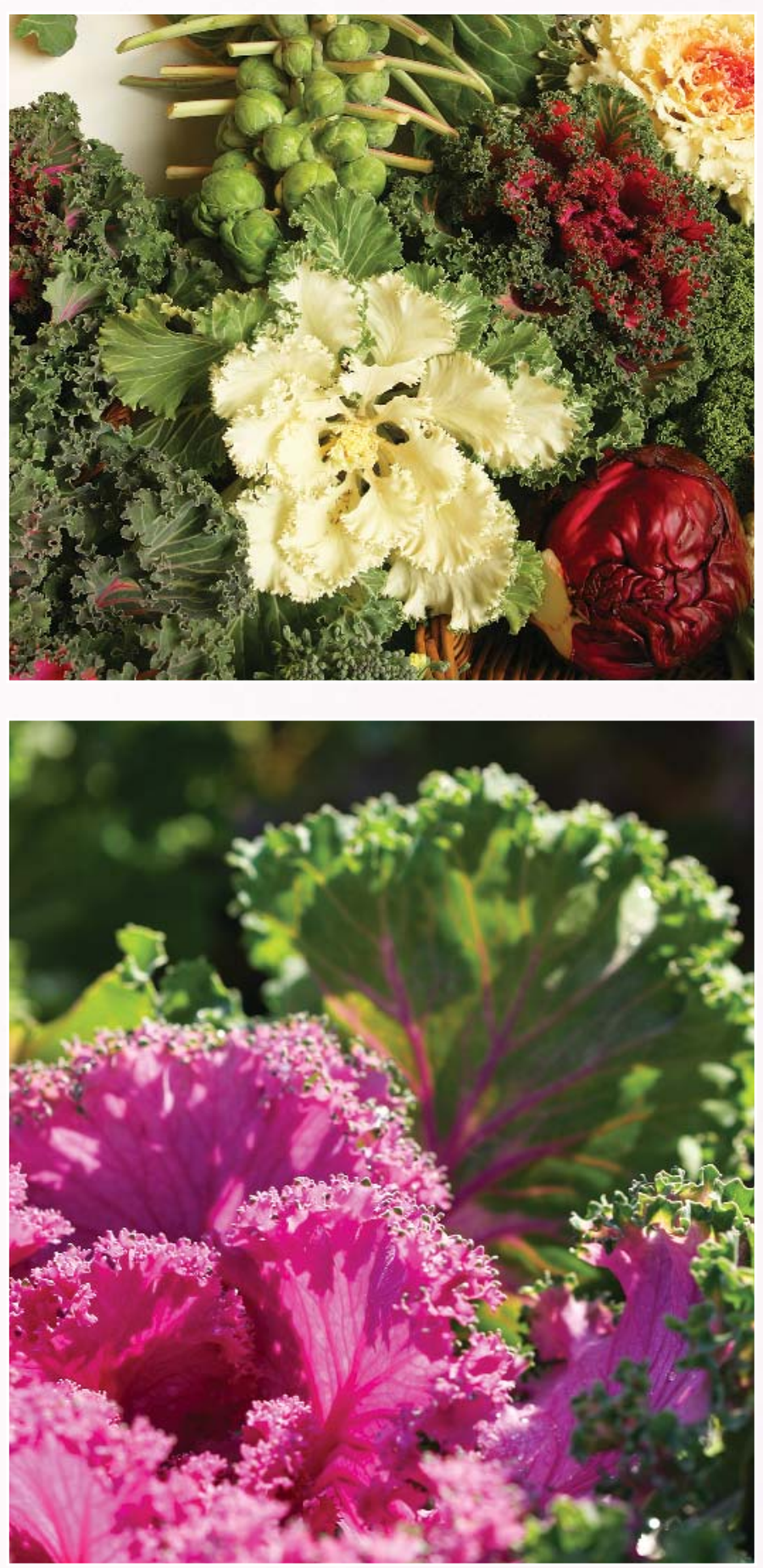


\section{ОВОЩНЫЕ РАСТЕНИЯ В ЭЛЕМЕНТАХ ЛАНДШАФТНОГО ДИЗАЙНА}

Искорка - среднепоздний сорт декоративной капусты пригодный для выращивания в открытом грунте, потребления в свежем виде, украшения блюд, интерьера, декоративного садоводства. Растение образует раскидистую розетку диаметром 32 - 45 см высотой 30-48 см. Лист сильно рассеченный на 13-23 сегмента с средним восковым налётом. Имеет гладкую ткань пластинки, слабо волнистую по краю листа со средней нервацией. Черешок длиной 6-10 см. Урожайность 5 -5,5 кг/м². Содержание витамина C - 45,76-49,28 мг\%, сухого вещества 8,98-9,78\%, сахаров 0,68-0,7\%. Сорт устойчив к бактериозам, листогрызущим вредителям, пониженным температурам.

Краски Востока - среднепоздний сорт декоративной капусть пригодный для выращивания в открытом грунте, потребления в свежем виде, украшения блюд, интерьера, декоративного садоводства. Растение имеет полураскидистую розетку диаметром 35-55 см, высотой 25-40 см. Окраска розетки серо-зелёная в крайнем ярусе плавно переходящая в фиолетовую в центре. Лист средней величины, округлый сильно волнистый по краю, центральная жилка фиолетовая. Черешок длинной 7-10 см. Урожайность 13-15 кг/м². Содержание витамина С 45,76-49,28 мг\%, сахаров 0,62 -0,68\%, сухого вещества 8,25-9,10\%.Сорт устойчив к бактериозам и листогрызущим вредителям, пониженным температурам.

Пальмира - среднеспелый сорт капусты декоративной пригодный для потребления в свежем виде, украшения блюд, интерьера, декоративного садоводства. Растение высотой 100-140 см в диаметре 40-50 см образует облиственную розетку с длинночерешковыми поникающими листьями. Лист цельный, округлый с сильногофрированными краями зеленой окраски. Урожайность - 10-12 кг/м² . Содержание витамина С колеблется от 40,48 до 44,0 мг\%, сахаров 0,64 - 0,70\%, сухого вещества 8,30 - 8,81\%. Сорт устойчив к пониженным температурам, относительно устойчив к бактериозам, фузариозу, киле.

Малиновка - среднеспелый сорт капусты декоративной пригодный для потребления в свежем виде, украшения блюд, интерьера, декоративного садоводства. Растение высотой 100-150 см в диаметре 40-50 см образует облиственную розетку с длинночерешко-

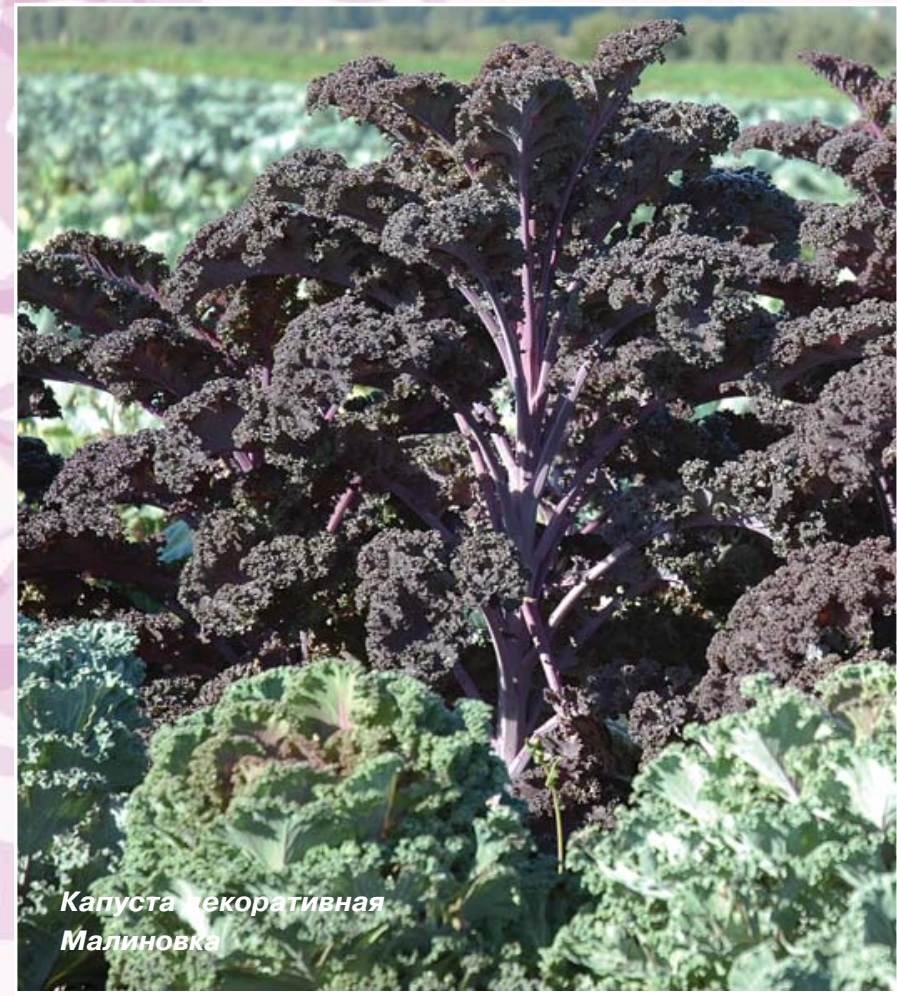

выми поникающими листьями. Лист цельный, округлый с сильногофрированными краями красно-фиолетовой окраски. Период от всходов до массового формирования розетки листьев 124-128 дней. Содержание аскорбиновой кислоты 45,76 49,28 мг на 100 г сырого вещества, общего сахара 0,62-0,68 \%, сухого вещества 8,32-9,15\%.Урожайность 12-15 кг/м².Устойчив к пониженным температурам, относительно устойчив к бактериозам, фузариозному увяданию, киле.

Снежная королева - среднепоздний сорт, пригоден для выращивания в открытом грунте. Используется для потребления в свежем виде, украшения блюд, интерьера, декоративного садоводства. Растение имеет компактную листовую розетку диаметром 40-55 см, высотой 35-50 см. Окраска - зелёная по краю, с ярким, беложелтым центром. Лист сильно рассечен, со слабым восковым налётом и ярко окрашенными бело-желтыми жилками. Имеет гладкую ткань листовой пластинки, со средней нервацией, слабо волнистую по краю. Черешок длиной 7-10 см. Урожайность 6,5-7,5 кг/м²

Ассоль - среднепоздний - сорт декоративной капусты пригодный для выращивания в открытом грунте, потребления в свежем виде, украшения блюд, интерьера, декоративного садоводства. Растение имеет компактную розетку листьев диаметром 35-45 см, высотой 3040 см. Окраска розетки светло-зелёная в крайнем ярусе плавно переходящая в бело-желтую в центре. Лист средней величины, округлый слабо волнистый по краю, центральная жилка светло-зеленая. Черешок длинной 5-

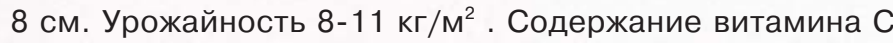
46,76-48,28 мг/100, сахаров 0,62-0,68\%, сухого вещества 8,5-9,0\%. Сорт устойчив к бактериозам и листогрызущим вредителям, пониженным температурам, проявление окраски не требует длительного воздействия пониженных температур.

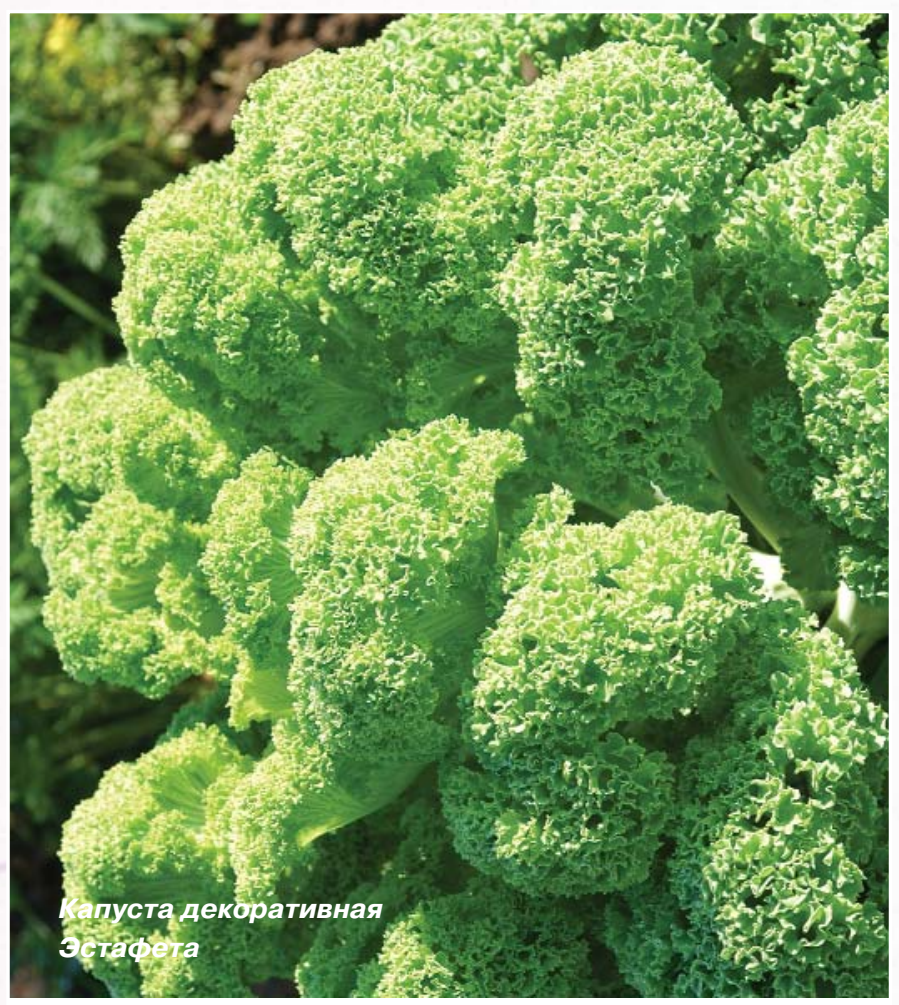

